\title{
Communication
}

[Comunicação]

\section{Poisoning by Enterolobium contortisiliquum pods in calves showing photosensitization and digestive lesions}

\author{
[Lesões digestivas e fotossensibilização em bezerros intoxicados pelas favas \\ de Enterolobium contortisiliquum]
}

\author{
C.C. Guizelini, R.C.P. Veiga, D.C. Gomes, C.S.L. Barros, R.A.A. Lemos
}

Faculdade de Medicina Veterinária e Zootecnia - Universidade Federal de Mato Grosso do Sul - Campo Grande, MS

\begin{abstract}
A number of Enterolobium species including $E$. contortisiliquum (Grecco et al., 2002; Mendonça et al., 2009), E. gummiferum and E. timbouva (Tokarnia et al., 2012) are toxic to cattle causing digestive signs, abortions and hepatogenous photosensitization. Spontaneous intoxication by E. contortisiliquum also occurs in goats and is associated with digestive disorders or abortions, but without photosensitization (Benicio et al., 2007).
\end{abstract}

Enterolobium spp. are well-developed trees, and intoxication occurs by ingestion of the pods that fall spontaneously to the ground or fall along with twigs that are torn by the wind, are pruned, or are reached by the animals in the lower parts of the tree (Grecco et al., 2002; Mendonça et al., 2009). Digestive disorders with or without photosensitization were experimentally reproduced by feeding cattle (Mendonça et al., 2009, Leal et al., 2017), sheep (Leal et al., 2017; Bacha et al., 2017; Pupin et al., 2017) and goats (Benicio et al., 2007) with the pods of $E$. contortisiliquum. The reported digestive clinical signs of E. contortisiliquum poisoning are usually described as non-specific and include diarrhea, anorexia, ruminal atony, apathy, and dehydration (Grecco et al., 2002; Mendonça et al., 2009).

Recently, based on experimental studies done in sheep fed with the pods of E. contortisiliquum at our laboratory (Bacha et al., 2017; Pupin et al., 2017), it was determined that such digestive signs results from ruminal acidosis due to the high content of non-fiber carbohydrates in the pods. Bromatological analysis of pods from $E$. contortisiliquum (Bacha et al., 2017) revealed 1:2.2 ratio between neutral detergent fiber corrected for protein and non-fiber carbohydrates, which is much higher than the 1:1 recommended ratio (Poore et al., 1993) to prevent depression in fiber digestion and preserve normal ruminal function. These results support the hypothesis that fermentable carbohydrates (starches and sugars) in the non-fermentable carbohydrate fraction of $E$. contortisiliquum pods may induce acute lactic ruminal acidosis.

Additionally, the gross and histopathological ruminal changes were characterized. The characterization of the digestive lesions of $E$. contortisiliquum poisoning as resultant from ruminal acidosis was yet unreported until the experiments performed by Bacha et al. (2017) and Pupin et al. (2017). The aim of this paper is to describe an outbreak of photosensitization and digestive lesions suggestive of ruminal acidosis in calves associated to ingestion of $E$. contortisiliquum pods in order to further confirm previous experimental studies.

The outbreak occurred in a farm in a small municipality $\left(21^{\circ} 41^{\prime} 56^{\prime \prime S} 57^{\circ} 52^{\prime} 58^{\prime \prime} \mathrm{W}\right)$ of the midwestern Brazilian, state of Mato Grosso do Sul, in October, 2018. There were 238 female and male calves aged 12-15 months, in poor body condition, raised in Brachiaria brizantha

Recebido em 24 de outubro de 2019 
pasture which contain lots of E. contortisiliquum trees in fruiting stage and others invasive plants. Besides the forage, the animals received only mineral supplement. Two days after the calves were introduced to this pasture, the clinical signs started and thirty-four of those got sick (morbidity rate of $12.7 \%$ ). The first manifestation observed was subcutaneous edema of the ventral jaw and neck that progressed to erythema and skin necrosis. Focally extensive red dermal areas (Figure 1A) was observed in portions where necrotic skin sloughed (Figure 1B).

These were interpreted as lesions of photosensitization (photodermatitis) and were typically located in the ventral aspect of the neck, dorsum, bilaterally in the flank and the posterior and medial aspect of both hindlimbs. The lesions varied in intensity among affected calves, and some calves had injuries in almost the whole skin surface. Some calves developed greenish malodorous diarrhea and drooling. Within 3-23 days from the onset of the clinical signs, fourteen calves died (mortality rate of $5.2 \%$ and a case fatality rate of $42.1 \%$ ). Two out of six adult dairy cows that were kept in the same pasture showed signs of photosensitization and recovered without any treatment. Even after the onset of the clinical signs, calves were not removed from the pasture.

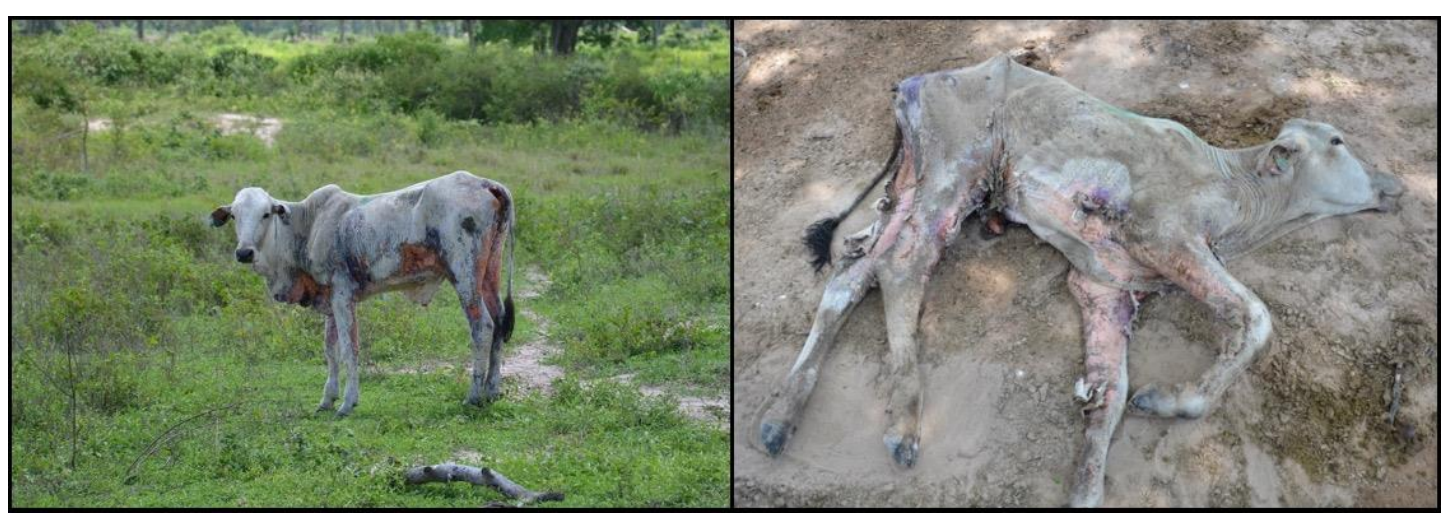

Figure 1. Poisoning by E. contortisiliquum pods in calves showing photosensitization and digestive lesions. A. There are focally extensive red areas of sloughed skin. B. Portions of necrotic skin are sloughing.

The authors made two on-site visits to the farm to collect data on the outbreak. Two calves were euthanized in extremis after being ill for five and 25 days, respectively. Necropsy findings were similar in both necropsied calves. They were in poor body condition and markedly dehydrated. There was paleness of conjunctiva and oral mucosa. Extensive alopecic, red and crusty areas of the skin were seen especially in the ventral aspect of the body. The rumen was moderately filled with dry pasture and there were numerous well-demarcated ulcers of $2-4 \mathrm{~cm}$ at the dorsal sac and ruminal pillars, with raised borders, and covered by yellow fibrillar material (Figure 2). The abomasal mucosa of one of the calves was similarly ulcerated (Figure 3), and $E$. contortisiliquum seeds was seen admixed with abomasal contents. Fragments of the abomasum, encephalon, forestomachs, Gasserian ganglia, heart, kidney, liver, large intestine, lung, pituitary, rete mirabilis, skin, small intestine, and spleen were collected in buffered $10 \%$ formalin and routinely processed for histopathology.

Histologically, the ruminal ulcers consisted of a deep base of granulation tissue covered by neutrophils, fibrin and cell debris (Figure 4). The abomasal lesions were similar but moderate. In the skin, there was coagulative necrosis of the epidermis with detachment and loss of most of the keratinocytes; numerous viable and degenerate neutrophils and fibrin covered the portions of skin deprived of the epidermis, forming a serocellular crust. Multifocal intraepithelial pustules occurred at sites where the integrity of the epidermis was conserved. There was no apparent edema of the underlying dermis but rather fibrovascular proliferation (granulation tissue). All the other organs were macroscopically and microscopically unaffected. 


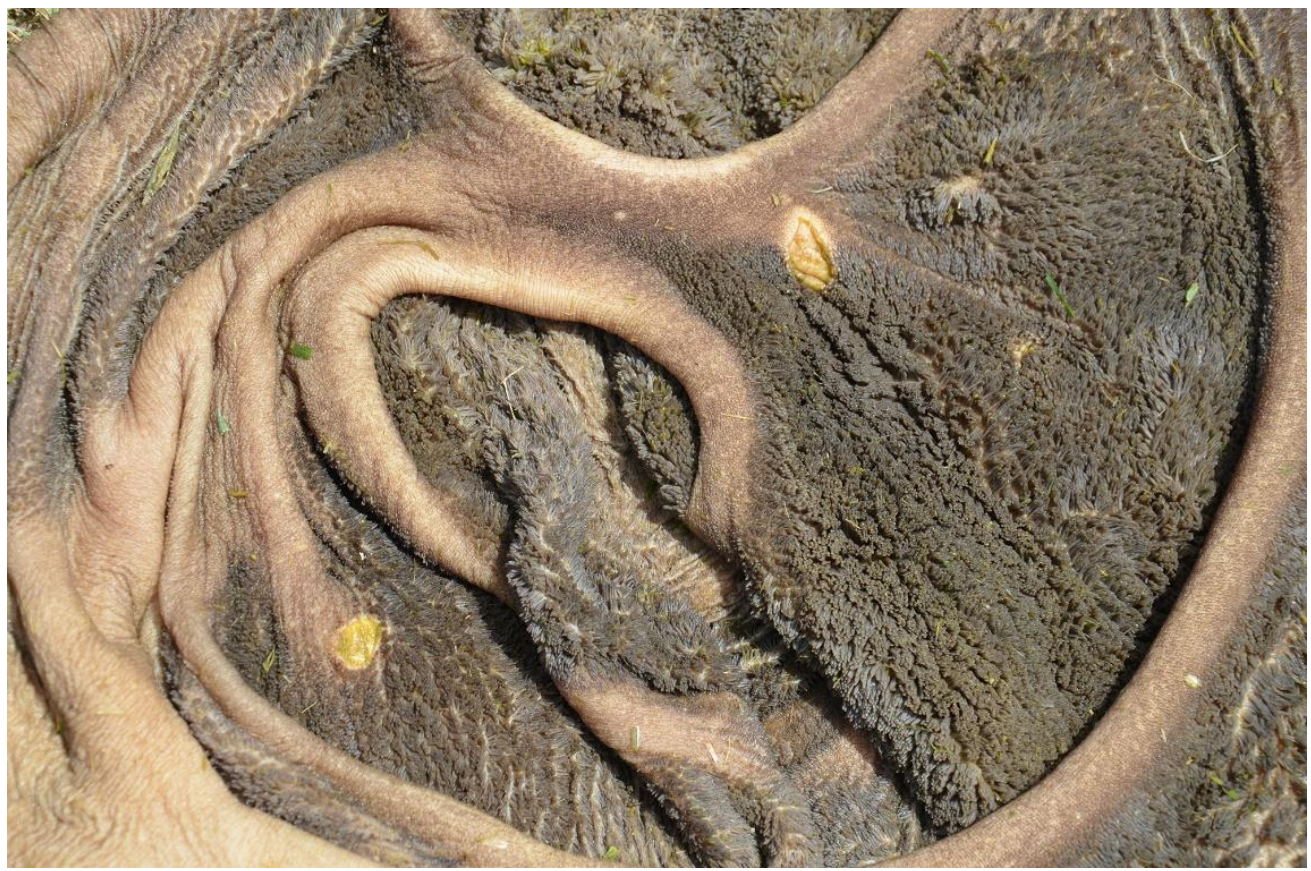

Figure 2. Poisoning by E. contortisiliquum pods in calves showing photosensitization and digestive lesions. Two well-demarcated ulcers of $2-4 \mathrm{~cm}$ in diameter located in the mucosa of the dorsal sac of the rumen and ruminal pillars. The ulcers have raised borders and are covered by yellow exudate.

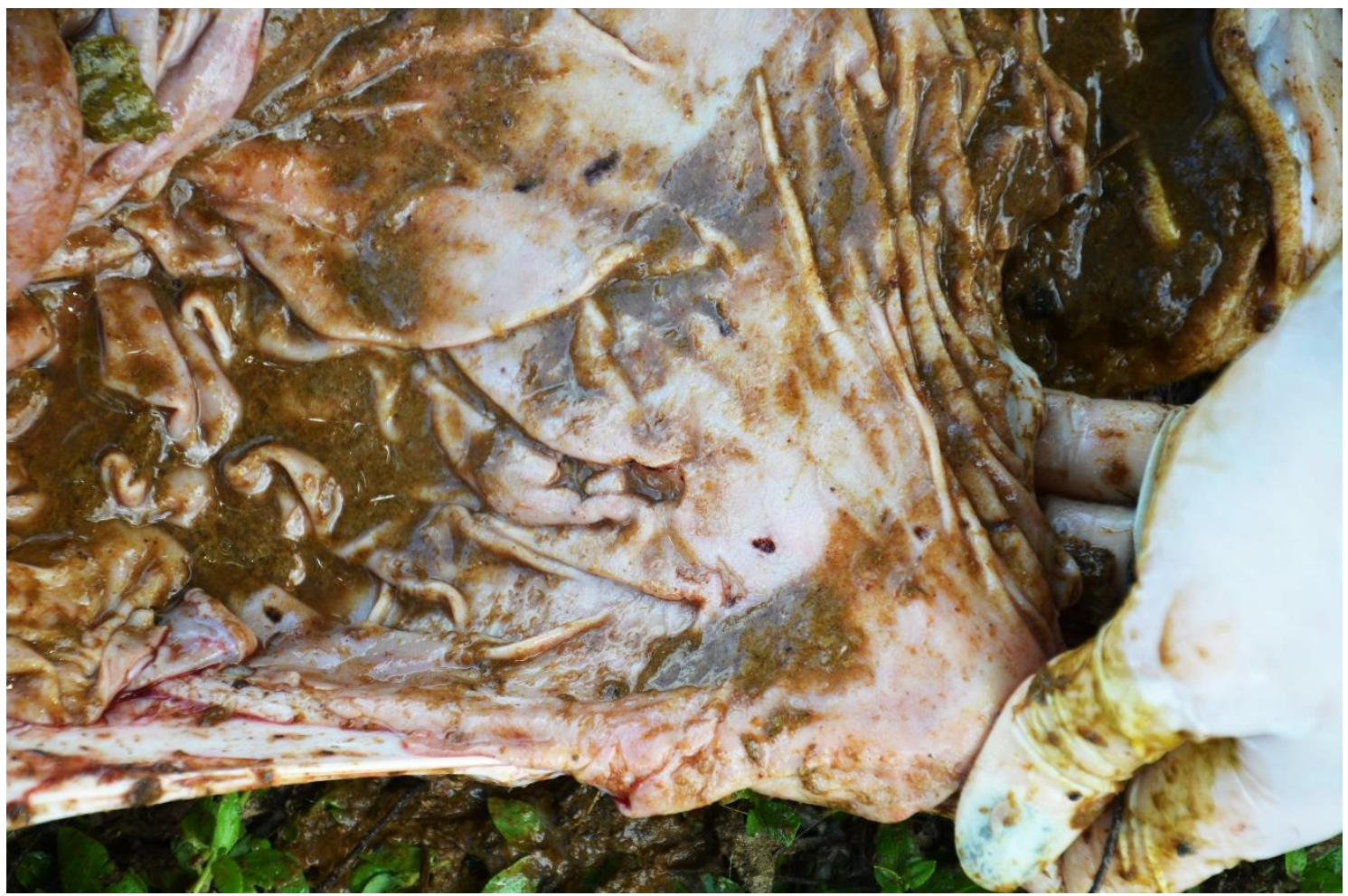

Figure 3. Poisoning by E. contortisiliquum pods in calves showing photosensitization and digestive lesions. The abomasal mucosa shows two deep ulcers with raising borders. 


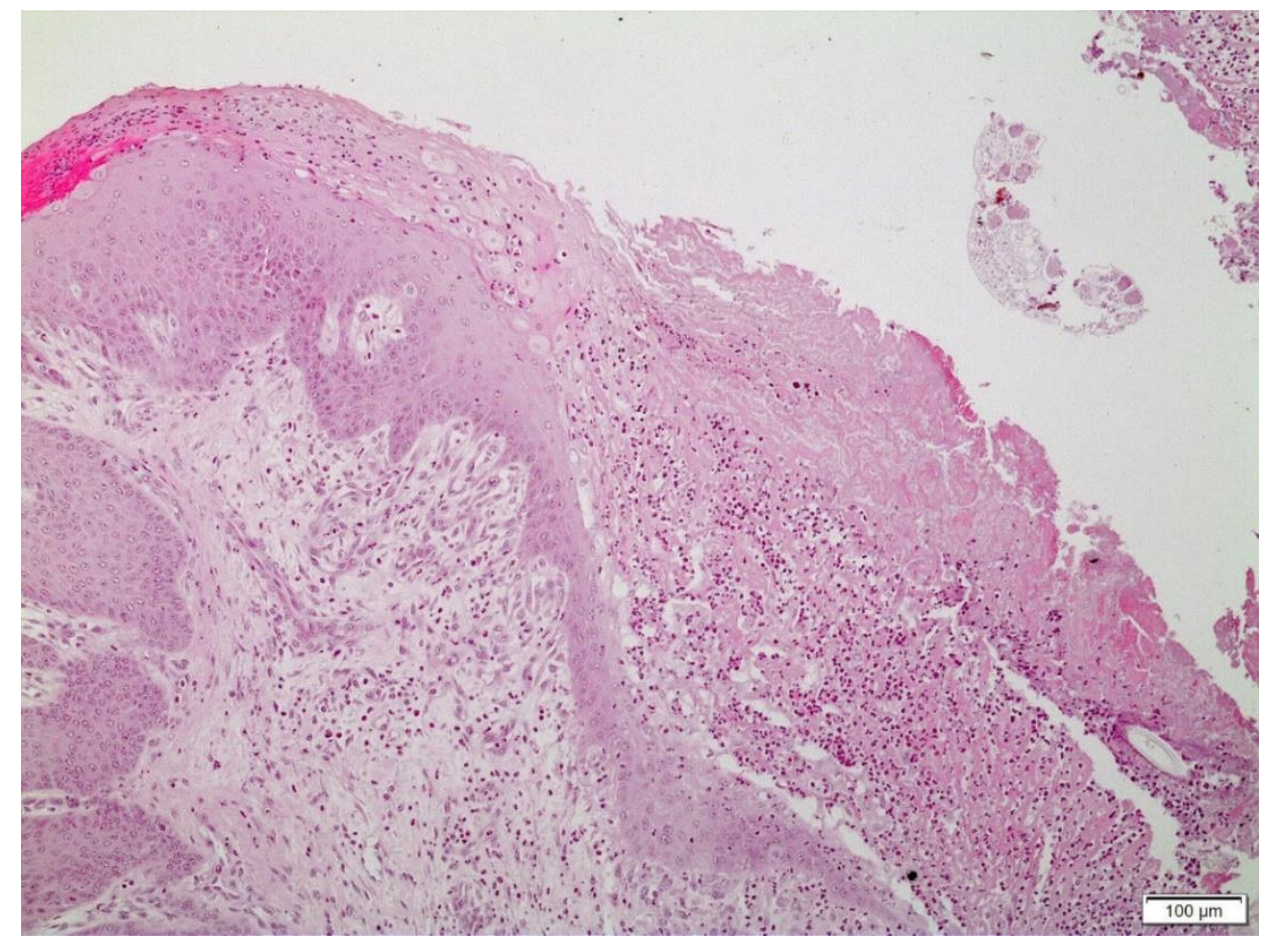

Figure 4. Rumen from a calf poisoned by the E. contortisiliquum pods. The epithelial had segmental loss due to coagulative necrosis. The epithelial gap is covered by serocellular exudate that rests on a base of granulation tissue (scarring). Neutrophils infiltrate the upper portion of the granulation tissue. HE.

In the current outbreak, E. contortisiliquum toxicosis occurred in 34 calves that fed on the pods of this plant. Some cattle died in the acute phase of the disease (but were not necropsied) and others developed subacute to chronic ruminal lesions. The following information was used to reach the diagnosis of $E$. contortisiliquum toxicosis in the current outbreak: (i) presence of E. contortisiliquum trees with large amounts of their pods fallen to the ground with evidence of being consumed by the affected cattle, (ii) cattle with clinical signs and lesions of photosensitization and digestive disorders, known to be associated with the poisoning by $E$. contortisiliquum in ruminants (Leal et al., 2017; Pupin et al., 2017), and (iii) presence of $E$. contortisiliquum seeds in the abomasum of one necropsied calf.

The findings in this outbreak could suggest for the first time an association between the occurrence of rumenitis due to acidosis and spontaneous intoxication by $E$. contortisiliquum in cattle. Spontaneous cases of ruminal acidosis occur in ruminants fed with large amounts of non-fiber carbohydrates (corn, wheat and barley) without prior adaptation (Nagaraja and Titgemeyer,
2007). As was already experimentally demonstrated (Bacha et al., 2017; Pupin et al., 2017), the pods of E. contortisiliquum have a high content of non-fiber carbohydrates which triggers ruminal acidosis. Drops in ruminal $\mathrm{pH}$ are associated with the accumulation of lactic acid, which potentially leads to ruminal acidosis (Hobson and Stewart, 1997). No attempt was made to determine the ruminal $\mathrm{pH}$ in the cases of this outbreak. However, ruminal $\mathrm{pH}$ is a diagnostic aid only in the acute phases of the disease since the $\mathrm{pH}$ rises in the subacute and chronic stages (Uzal et al., 2016). In the same way, the ruminal content that is copious and porridge-like in the acute phases of ruminal acidosis may assume a healthy appearance over time and present itself even parched with the progression of the condition, although a poor nutritional state persists (Uzal et al., 2016).

Acute ruminal acidosis is the first clinical manifestation of naïve sheep fed with pods of $E$. contortisiliquum (Bacha et al., 2017; Pupin et al., 2017) and also in cattle (Leal et al., 2017). Sheep may die at this stage or recover, but photosensitization wasn't seen; however, in cattle, those which recovered had photosensitization 
(Leal et al., 2017), as observed in the calves of the current outbreak, since the plant is highly hepatotoxic (Leal et al., 2017). Hepatic lesions were not seen in the two necropsied calves, which could be due to the reversibility of hepatic lesions, similarly to those observed in a previous study (Leal et al., 2017). As the necropsied calves were in a subacute or chronic phase of the disease, it is most likely that the liver lesions had already regenerated, without scarring; the same does not apply to the ruminal ulcers. In animals that survive the acute phase of ruminal acidosis, hydropic degeneration and necrosis of the ruminal epithelial supervenes. The unprotected ruminal mucosa is then subject to invasion by bacteria or fungi. Animals that also survive this stage will develop ulcers (Uzal et al., 2016), similar to those found in the two necropsied cattle in this study.

Intoxications by other plants that cause similar clinical manifestations as Stryphnodendron fissuratum (Lazaro et al., 2018) and Brachiaria spp. (Riet-Correa et al., 2011) were ruled out in the differentials due to the absence of $S$. fissuratum in the property, and due to the absence of hepatic lesions characteristic of Brachiaria spp. poisoning, which includes clusters of foamy macrophages, cholestasis and birefringent crystals in the lumen of bile ducts (Riet-Correa et al., 2011).

\section{ACKNOWLEDGMENT}

This study was partially funded by the Coordenação de Aperfeiçoamento de Pessoal de Nível Superior - Brasil (CAPES) - Finance Code 001 and by Fundação de Apoio ao Desenvolvimento do Ensino, Ciência e Tecnologia do Estado de Mato Grosso do Sul (FUNDECT). Two of the authors (Lemos R.A.A. and Barros C.S.L.) have a fellowship from Conselho Nacional de Desenvolvimento Científico e Tecnológico (CNPq), Brazil (309074/2018-5 and PQ-1A \# 302300/2013-9, respectively).

Keywords: cattle diseases, plant poisoning, ruminal acidosis, photosensitization

\section{RESUMO}

Este trabalho descreve um surto de rumenite e abomasite decorrente de sobrecarga de carboidratos em um rebanho de 238 bezerros, com idades entre 12 e 15 meses, causada pela ingestão dos frutos de Enterolobium contortisiliquum. As taxas de morbidade, mortalidade e letalidade foram de, respectivamente, 12,7\%, 5,2\% e 42,1\%. Clinicamente, os bovinos apresentaram fotossensibilização, salivação e diarreia. Os achados de necropsia foram semelhantes nos dois bezerros necropsiados e consistiram de fotodermatite e rumenite ulcerativa multifocal, subaguda a crônica, e abomasite. A relevância deste relato é que, pela primeira vez, foi possível associar a ocorrência da rumenite devido à sobrecarga de carboidratos com a intoxicação espontânea por E. contortisiliquum em bovinos, confirmando achados anteriormente descritos em experimentos realizados com ovinos.

Palavras-chave: doenças de bovinos, intoxicação por plantas, acidose ruminal, fotossensibilização

\section{REFERENCES}

BACHA, F.B.; PUPIN, R.C.; LEAL, P.V. et al. Experimental poisoning by Enterolobium contortisiliquum in sheep. Pesq. Vet. Bras., v.37, p.23-30, 2017.

BENÍCIO, T.M.A.; NARDELLI, M.J.; NOGUEIRA, F.R.B. et al. Intoxication by the pods of Enterolobium contortisiliquum in goats. In: PANTER, K.E.; WIERENGA, T.L.; PFISTER, J.A. (Eds.). Poisonous plants: global research and solutions. Wallingford, Oxon: CABI Publishing, 2007. p.80-85.
GRECCO, F.B.; DANTAS, A.F.M.; RIETCORREA, F. et al. Cattle intoxication from Enterolobium contortisiliquum pods. Vet. Hum. Toxicol., v.44, p.160-162, 2002.

HOBSON, P.N.; STEWART, C.S. (Eds.). The rumen microbial ecosystem. New York: Chapman and Hall, 1997. 719p.

LAZARO, D.N.; BACHA, F.B.; PUPIN, R.C. et al. Photosensitization in cattle caused by spontaneous and experimentally ingestion of Stryphnodendron fissuratum. Acta Sci. Vet., v.46, p.1-8, 2018. 
LEAL, P.V.; PUPIN, R.C.; LIMA, S.C. et al. Ingestion of the pods of Enterolobium contortisiliquum causes hepatogenous photosensitization in cattle. Toxicon, v.131, p.610, 2017.

MENDONÇA, F.S.; EVÊNCIO-NETO, J.; EVÊNCIO, L.B. et al. Natural and experimental poisoning of cattle by Enterolobium contortisiliquum pods (Fabaceae Mimosoideae) in Central-Western Brazil. Acta Vet. Brno, v.78, p.621-625, 2009.

NAGARAJA, T.G.; LECHTENBERG, K.F. Acidosis in feedlot cattle. Vet. Clin. N. Am. Food Anim. Pract., v.23, p.333-350, 2007.

POORE, M.H.; MOORE, J.A.; SWINGLE, R.S. et al. Response of lactating Holstein cows to diets varying in fiber source and rumen starch degradability. J. Dairy Sci., v.76, p.2235-2243, 1993.
PUPIN, R.C.; LEAL, P.V.; LIMA, S.C. et al. Enterolobium contortisiliquum is a cause of acute ruminal acidosis in sheep. Toxicon, v.126, p.9095, 2017.

RIET-CORREA B.; CASTRO, M.B.; LEMOS, R.A.A. et al. Brachiaria spp. poisoning of ruminants in Brazil. Pesq. Vet. Bras., v.31, p.183192, 2011.

TOKARNIA, C.H.; BRITO, M.F.; BARBOSA, J.D. et al. (Eds.). Plantas tóxicas do Brasil para animais de produção. Rio de Janeiro: Helianthus, 2012. 586p.

UZAL, F.A.; PLATTNER, B.L.; HOSTETTER, J.M. Alimentary system. In: MAXIE, M.G. (Ed.). Jubb, Kennedy, and Palmer's pathology of domestic animals. Philadelphia: Elsevier Saunders, 2016. v.2, p.1-257. 